\title{
The Difference in the Effect of Teaching Style and Kinesthetic Perception on Learning Outcomes in Passing in Soccer Games
}

\author{
Daud Rivai Harahap \\ Post Graduate Program, Universitas \\ Negeri Medan \\ Medan, Indonesia. \\ daudharahap73@yahoo.com
}

\author{
Imran Akhmad \\ Sport education courses, Universitas \\ Negeri Medan \\ Medan, Indonesia
}

\author{
Novita \\ Sport education courses, Universitas \\ Negeri Medan \\ Medan, Indonesia
}

\begin{abstract}
Abstrak - This research will be carried out in MAN 2 Medan Model. The stages of this study include collecting data about kinesthetic perception, applying teaching style, and collecting data about the results of learning passing in soccer games. The treatment style of teaching chosen was the guided discovery style and the reciprocal style. The time to apply the teaching style treatment is done for 4 weeks. With research time, there were 4 meetings. The research design used is by level $2 \times 2$ with three research variables, namely one dependent variable and two independent variables. As the dependent variable (dependent variable) is the result of learning passing in a soccer game and two independent variables are teaching styles and student kinesthetic perception. The hypotheses in this study are: 1) There are differences in the results of learning passing in soccer games between The Guided Discovery Style and The Reciprocal Style. 2) There is an interaction between teaching style and kinesthetic perception on the results of learning to pass in a soccer game. 3) Students taught with The Reciprocal Style with high kinesthetic perception are better than students taught with The Guided Discovery Style with high kinesthetic perception. 4) Students taught with The Guided Discovery Style with low kinesthetic perception are better than students taught with The Reciprocal Style with low kinesthetic perception.
\end{abstract}

Keywords - Teaching Style; Kinesthetic Perception on Learning; Passing Soccer Games

\section{INTRODUCTION}

We agree that education is something that is familiar to us, especially because we are engaged in education. In fact, it can be said that this education is experienced by all people of all groups. But often people forget the meaning and nature of education itself. Like other things that have become routine, tend to be forgotten the basic meaning and nature. In the intensification of education as a process of human development that lasts a lifetime. Ki Hajar Dewantara defines education as an effort to advance the character, mind and body of the child, so as to advance the perfection of life and revive children in harmony with nature and society.

Law of the Republic of Indonesia number 20 of 2003 concerning the National Education System (National Education System Law) formulates the functions and objectives of national education that must be used to develop national education in Indonesia. Article 3 of the National Education System Law states, "National education functions to develop and shape dignified national character and civilization in order to educate the lives of the nation, with the aim of developing the potential of students to become faithful and fearful people of God Almighty, noble, healthy, knowledgeable, capable, creative, independent, and a democratic and responsible citizen.

Physical education can also be interpreted as an educational process through physical activities designed to improve physical fitness, develop motor skills, healthy and active knowledge and behavior, sportsmanship, and emotional intelligence. The learning environment is carefully regulated to improve the growth and development of all domains, physical, psychomotor, cognitive, and affective of each student.

In accordance with the opinion of Husdarta physical education is an important part of the educational process. This means that physical education is not only a decoration or ornament attached to a school program as a tool to keep children busy. Based on the above understanding, it can be concluded that physical education is an educational process carried out through physical activities that can achieve a child's cognitive, psychomotor and affective goals [4].

The role of Physical Education is very important, which provides opportunities for students to be directly involved in various learning experiences through physical activities, play and sports that are carried out systematically. Debriefing the learning experience is directed to fostering, as well as forming a healthy and active lifestyle throughout life, and loving the environment through health education and outdoor activities that are applied in various ways.

Physical education curriculum consists of several submaterials, one of which is a soccer game. Football is the most popular sport in the world. In essence, soccer games are team games that use soccer balls. Football was played on grass by two teams facing each other with each team consisting of eleven players including one goalkeeper. The purpose of the 
game is to play as much as possible into the opponent's goal and try to defend his own goal from the opponent's attack so as not to concede a goal [7].

To play ball well players are provided with good basic techniques. Players who have good basic techniques tend to play well too. Some basic techniques learned from the SMA / MA curriculum are passing, controlling, dribbling, heading, kicking, throwing in. In this study the material discussed was passing.

Passing is the process of pushing a ball with a certain leg to a friend. The main goal of passing is to flow the ball to create an opportunity to score goals and so that the opposing player is not easy to grab possession because the ball is kept away from the opponent by passing. Some soccer passing techniques refer to how a player executes his movements. The division is based on the use of feet in passing. Passing can be done with the techniques of deep legs, outside legs, or even with the toes. According to Sucipto "Kicking a ball is one of the most dominant characteristics of soccer players". Kicking the ball is mostly done in football games when compared to other techniques, so it is only natural that in every practice many techniques are taught to kick the ball [7]. According to Sarumpaet Passing is an attempt to move the ball from one place to another using the foot or leg [6]. Kicking the ball can be done in a state of silent ball, rolling or floating in the air. One of the facts of how passing learning in soccer in the field is that students are only told to pass without knowing the technique of doing actual passing, as well as learning to be monotonous, not given cognitive understanding to students where students must understand what, how and why passing is done, then teaching style which does not arouse student learning motivation, as well as limited student ability to move. Based on observations made on students of MAN 2 Medan Model, it was found some problems where 1) Students tend to play football regardless of good techniques, 2) Lack of student motivation, especially for female students, 3) Soccer learning is only done by male students male, 4) Football learning is not as attractive as possible, but the teacher only gives the ball and students play freely without being taught good techniques with the application of interesting learning, 5). Lack of application of teaching styles that are interesting by the teacher, thus making students feel bored with learning physical education. 6) Based on direct interviews with students of MAN 2 Medan Model where students especially complained about passing material in soccer where students were not interested at all especially for female students.

Based on the above problems, the researcher determines the teaching style of Muska Mosston as a consideration. In this study the teaching style of the guided discovery style style and the reciprocal style was chosen as a treatment in this study. The guided discovery style style or also called guided and guided discovery style according to the translation from English. The defining characteristic of the guided discovery style according to Mosston, is the design of logical and sequential questions that direct someone to find a predetermined response [5]. In the anatomy of guided discovery, the teacher's role is to make all key decisions, including the concept of the target which will be found in the sequential design of questions for students. The purpose of this style according to Mosston is to find alternative answers in the form of motion that the teacher asks. The essence of this behavior is the teacher-student relationship where the teacher's question sequence carries a series of responses that are appropriate for the students [5].

The reciprocal method approach gives students the freedom to make decisions regarding the execution of tasks, students are given the obligation to assess learning outcomes in a limited way [2]. Assessment is limited to the assessment of formatid or corrective by someone against a student or group of students. According to Husdarta this reciprocal style begins with attention to greater changes, in making decisions from teachers to students. Students are responsible for observing the appearance of their friends or partners and giving feedback immediately when making a move [4].

Not only does it relate to teaching style in increasing the results of learning passing in soccer games. However, other aspects are enough to influence student learning outcomes, one of which is kinesthetic perception. To be able to do the technique properly and correctly, a nervous system is needed which is closely related to one's feelings towards the object they play. This feeling is called kinesthetic perception or feeling or awareness of the position of the body in time to move. Kinesthetic perception is important to control movements more accurately [3]. If someone commits a technical error, the child who has good kinesthetic perception will immediately find out the error. In other words, the perfection of a technique can usually only be done by people who detect the pattern of movement the fastest and this person is called to have good kinesthetic perception.

Kinesthetic perception is also called the kinesthetic sense (kinestetics sense), which means sensory input that occurs in the body. Body attitudes and movement information are communicated through the sensory system by stretching the muscles in the body. Even in a state of silence, the kinesthetic senses can monitor body position. So the kinesthetic senses are a function of human organs that are closely related to body movements. A more operational understanding of kinesthetic perception is the ability to take positions and body movements, as well as their parts [1]. From some of the information above, it can be concluded that Kinesthetic Perception is a feeling that arises because of stimuli from muscle receptors, muscle fascia, tendons and joints that act as feedback mechanisms that give individuals awareness of body position or parts of the body in controlling movements with more precise or accurate.

Based on this, the researchers conducted a study entitled "The Difference in the Effect of Teaching Style and Kinesthetic Perception on Learning Outcomes in Football Games in Students in Medan Class XI MAN 2 Model". 


\section{METHOD}

The research was conducted using the experimental method. The experimental method is a research method that is used to find out the influence of certain treatments (Sugiyono, 2010: 12). In this study, we compared two different teaching styles, namely the guided discovery style and the reciprocal style with the attributes of student kinesthetic perception consisting of high kinesthetic perception and low kinesthetic perception.

The research design used is by level $2 \times 2$ with three research variables, namely one dependent variable and two independent variables. As the dependent variable (dependent variable) is the result of learning passing in a soccer game and two independent variables are teaching styles and student kinesthetic perception.

\section{RESUlt AND DISCUSSION}

This research will be carried out in MAN 2 Medan Model. The stages of this study include collecting data about kinesthetic perception, applying teaching style, and collecting data about the results of learning passing in soccer games. The guided discovery style and the reciprocal style. The guided discovery style and the reciprocal style were carried out for 3 weeks. With research time, there were 4 meetings. The research was conducted using the experimental method. The experimental method is a research method that is used to find out the influence of certain treatments. In this study, we compared two different teaching styles, namely the guided discovery style and the reciprocal style with the attributes of student kinesthetic perception consisting of high kinesthetic perception and low kinesthetic perception. The research design used is by level $2 \times 2$ with three research variables, namely one dependent variable and two independent variables. As the dependent variable (dependent variable) is the result of learning passing in a soccer game and two independent variables are teaching styles and student kinesthetic perception. The hypotheses in this study are: 1) There are differences in the results of learning passing in soccer games between The Guided Discovery Style and The Reciprocal Style. 2) There is an interaction between teaching style and kinesthetic perception on the results of learning to pass in a soccer game. 3) Students taught with The Reciprocal Style with high kinesthetic perception are better than students taught with The Guided Discovery Style with high kinesthetic perception. 4) Students taught with The Guided Discovery Style with low kinesthetic perception are better than students taught with The Reciprocal Style with low kinesthetic perception.

\section{References}

[1] Barry L Johnson and Jack K Nelson. 1979. Practical Measurement For Evaluation Physical Educaton.Third Edition. USA: Burgess Publishing Company.

[2] Ega Trisna Rahayu. 2013. Strategi Pembelajaran Pendidikan Jasmani. Implementasi Pada Pembelajaran Pendidikan Jasmani, Olahraga Dan Kesehatan. Bandung: CV Alfabeta.

[3] Harsono. 1988. Aspek-aspek Psikologi dalam Coaching. Jakarta: CV. Tambak Kusuma Jakarta.

[4] Husdarta Dan Yudha M. Saputra. 2013. Belajar Dan Pembelajaran Pendidikan Jasmani Dan Kesehatan. Bandung: CV. Alfabeta.

[5] Muska Mosston. 2008. Teaching Physical Education. Finland: University Of Jyvaskyla.

[6] Sarumpaet. 1992. Permainan Besar. Jakarta: Departemen Pendidikan dan Kebudayaan,

[7] Sucipto. 2000. Sepakbola. Jakarta: Departemen Pendidikan Nasional. 